\section{Health transition in Brazil: regional variations and divergence/convergence in mortality}

\author{
A transição da saúde no Brasil: variações \\ regionais e divergência/convergência na \\ mortalidade
}

\author{
La transición de la salud en Brasil: variaciones \\ regionales y divergencia/convergencia en \\ la mortalidad
}

Gabriel Mendes Borges 1,2

doi: 10.1590/0102-311X00080316

\begin{abstract}
This study analyzes the main characteristics of the health transition in Brazil and its five major regions, using a framework that accounts for regional inequalities in mortality trends. The regional mortality divergence/convergence process is described and discussed by considering the specific contributions of age groups and causes of death in life expectancy variations. Results show that mortality change in Brazil has follow the epidemiologic transition theory to some extent during the period under analysis - for instance, the sharp decline in infant mortality in all regions (first from infectious and parasitic diseases and then from causes associated with the perinatal period) and the increase in the participation of chronic and degenerative diseases as the main cause of death. However, some features of Brazilian transition have not followed the linear and unidirectional pattern proposed by the epidemiologic transition theory, which helps to understand the periods of regional divergence in life expectancy, despite the long-term trends showing reducing regional inequalities. The emergence of HIV/AIDS, the persistence of relatively high levels of other infections and parasitic diseases, the regional differences in the unexpected mortality improvements from cardiovascular diseases, and the rapid and strong variations in mortality from external causes are some of the examples.
\end{abstract}

Health Transition; Cause of Death; Demographic Analysis
Correspondence

G. M. Borges

Instituto Brasileiro de Geografia e Estatística.

Av. Presidente Antonio Carlos 25, sala 803, Rio de Janeiro, RJ 20020-010, Brasil.

gmendesb@hotmail.com

1 Instituto Brasileiro de Geografia e Estatística,

Rio de Janeiro, Brasil.

2 University of California, Berkeley, U.S.A. 


\section{Introduction}

Epidemiologic transition is a concept first used by Omran ${ }^{1}$ to explore the complex change in patterns of health and disease. This theory is based on the idea that degenerative and the so-called "man-made" diseases replaced infectious diseases as the primary causes of morbidity and mortality, following these three successive stages: (i) the "Age of Pestilence and Famine", when mortality is high and fluctuating; (ii) the "Age of Receding Pandemics", when mortality declines progressively; and (iii) the "Age of Degenerative and Man-Made Diseases", when mortality continues to decline and eventually approaches stability at a relatively low level.

These stages vary in pattern, pace, and determinants, leading to different models of the epidemiologic transition: the first one is the "classical" or Western model, which shows a gradual and progressive transition that was supposed to happen in most of the developed world. The contemporary or delayed model refers to the transition yet-to-be completed in most developing countries. The third one is the accelerated mortality transition model, which occurred most notably in Japan.

In agreement with the original epidemiologic transition idea, some authors consider an additional fourth stage, called "The Age of Delayed Degenerative Diseases". This concept includes a rapid decline in mortality, concentrated mostly at advanced ages and caused by the postponement of mortality from degenerative diseases 2,3 .

Omran revisited the original epidemiologic transition theory in 1998, adding a fourth stage that allows declining in cardiovascular diseases mortality, ageing, emerging diseases, and changing lifestyles, in addition to a fifth futuristic stage. He also recognizes different stages of the transition in non-Western societies, with the third stage being the "Age of Triple Health Burden" 4.

The original epidemiologic transition theory presupposes an implicit convergence in its last stage, since mortality would stabilize at very low levels. This is also a general premise of the demographic transition theory, for both fertility and mortality 5 , in addition to being used in most population projections, including the official population projection of Brazil and its states 6 .

However, important failures and unexpected improvements contradict key points of the epidemiologic transition theory. Some authors argue that Omran's "Age of Degenerative and Man-Made Diseases" is not the final stage of the transition and the successful fight against cardiovascular diseases cannot be interpreted as its fourth stage. Rather, these changes should fit into a divergence/convergence process, based on an alternative approach to health, in which success in this field depends on societies' abilities to implement progresses 7 .

Lerner 8 was the first to present a formulation that considers the epidemiologic transition as part of this broader concept of "health transition". This idea was further explored 9 , including elements of the social conceptions and behaviors regarding health determinants and consequences of health change. This approach, according to the authors, has the advantage of being sufficient for application in different contexts, in opposition to the epidemiologic transition theory, which does not completely take into account the complexity of several transition patterns observed within and between different countries.

The main criticisms of the epidemiologic transition theory are related to the existence of a linear and unidirectional view of the processes and the sequence of the stages. It has been observed that actual transitions often contain many nonlinear processes, in addition to an overlapping of different patterns 9 .

Transformations resulting from health transition are particularly complex in middle-income countries. In Latin America, for example, mortality improvements have been reflecting advances in medical technology, progresses in health care systems, and changes in lifestyles and living conditions of the populations 10 . However, the health profile is very heterogeneous, which leads to the development of a peculiar epidemiologic polarization, not only among countries, but also within them in different geographic areas and among different social classes. This complex epidemiologic profile coexists with challenges related to the complexity of the organization of health systems 9,11. These experiences are called "prolonged polarized model", and paradigmatic examples can be observed in Brazil and Mexico 12. Polarization is associated with the concept of double burden of infectious and chronic diseases, but this model also emphasizes the existence of a "protracted" period, when these two kinds of disease coexist, without a clear expectation of resolving the transition process, mostly due to the persistence 
of social and regional inequalities. These inequalities reinforce this pattern as a result of subpopulations experiencing different stages of the transition, but also because these subpopulations themselves frequently suffer from both types of diseases - infectious and degenerative - simultaneously.

The epidemiologic transition in Brazil has not followed the model experienced by most developed countries. Old and new health problems coexist: despite the predominance of chronical and degenerative diseases, the communicable ones still play an important role. The introduction of diseases such as Zika, the reintroduction of dengue and cholera, and the intensification of others like malaria, leprosy, and leishmaniasis indicates a non-unidirectional nature in the process, also called counter transition 13. Such a counter transition, referring to the resurgence of these infectious and parasitic diseases, does not have a large impact on overall mortality trends, even though short-run increases in mortality from infectious diseases have been observed 10,14,15. However, this process has great importance for morbidity 16 . Another example contradicting the main aspects of the theory is mortality from external causes, which has been playing an important role in changing mortality patterns in the country 17 .

In this context, the objective of this study is to analyze the main characteristics of the health transition in the five major regions of Brazil, considering the great regional inequalities in the country. The regional mortality divergence/convergence process is described and discussed by taking into account the specific contributions of age groups and causes of death in life expectancy variations.

For this purpose, this study uses the health transition approach 9 , which emphasizes the importance of defining a research agenda paying particular attention to the subnational level, so that social and regional inequalities in health may be better documented. It also employs a methodology that analyzes convergences and divergences in mortality 7 , considering specific age groups and causes of death.

\section{Methods}

This study concentrates on the period of 1980-2010, for which life tables using administrative records and information by causes of death are available. It also uses secondary data sources to describe overall mortality trends for early years.

Life expectancy estimations come from the official life tables released by the Brazilian Institute of Geography and Statistics (IBGE) by five-year age groups (except for the first group, which is disaggregated in 0-1 and 1-4), sex, and major region, for the years 1980, 1991 18, 2000, and 201019. These life tables were constructed using the information of deaths from the Civil Registration System, vital statistics from the Brazilian Ministry of Health (Brazilian Mortality Information System SIM), and census population counts for the corresponding years. The life tables have been corrected by the IBGE, due to the underestimation of infant 20,21 and adult mortality $22,23,24$, using indirect estimation methods.

In order to maintain temporal consistency in the estimates, two adjustments were made. The first one aimed to reconstruct the life tables for the North and Central regions in 1980, considering the territorial adjustment necessary to account for the separation of Tocantins from Goiás State, as it became part of the North region. The second adjustment concerns a procedure adopted when building the 1991 life tables, in which reduction factors were applied to the rates at older ages 18. To maintain the methodological comparability in the procedures adopted for the other years (1980, 2000, and 2010), the mortality rates for 1991 were adjusted using the inverse of the reduction factors.

The data on deaths by major region, age, sex, and cause of death from 1980, 1991, 2000, and 2010 (three-year moving average) came from SIM (Brazilian Health Informatics Department. http://tabnet. datasus.gov.br/cgi/tabcgi.exe?sim/cnv/obt10uf.def, accessed on 15/May/2015). Causes of death were grouped using the 9th and 10th International Classification of Disease (ICD-9 and ICD-10), as follows: IPD - infectious and parasitic diseases (ICD-10 chapter I; ICD-9 chapter 1); NEO - neoplasms (ICD-10 chapter II; ICD-9 chapter 2); DCC - diseases of the circulatory system (ICD-10 chapter IX; ICD-9 chapter 7); DRS - diseases of the respiratory system (ICD-10 chapter X; ICD-9 chapter 8); DDS - diseases of the digestive system (ICD-10 chapter XI; ICD-9 chapter 9); PER - perinatal affections (ICD-10 chapter XVI; ICD-9 chapter 15); CON - congenital affections (ICD-10 chapter XVII; 
ICD-9 chapter 14); EXT - external causes (ICD-10 chapter XX; ICD-9 chapter 17); and OTH - others (remaining chapters, not listed previously).

Limitations in the mortality information regarding the cause of death persist, despite improvements over time. There are also great regional differences in data quality and, in areas where the proportion of ill-defined causes of death is high, no evidence that the proportional distribution of well-defined deaths is a suitable procedure exist 25,26 . For this reason, cause of death information was only used when it was considered to be of adequate quality according to the definition by Mathers et al. 27 (i.e., ill-defined codes for the underlying cause appear on fewer than $20 \%$ of the death certificates). In these cases, deaths of ill-defined causes were redistributed proportionally by age group, sex, and year. Thus, decompositions by age and cause of death were performed for Brazil and the Southeast, South, and Central regions, but not for the North and Northeast regions, for which gains in the life expectancy were decomposed only by age groups. The proportional redistribution of ill-defined deaths may include some bias in the results of the decompositions by cause of death, even though this was done only for the regions that have relatively low proportion of ill-defined causes of death, including Brazil as a whole.

The method used to estimate variations in life expectancy over time due to changes in mortality by age and cause of death is the one described by Shkolnikov et al. 28 :

$$
\varepsilon_{x}=e_{x}^{2}-e_{x}^{1}=\frac{1}{2} \sum_{x}^{w}\left\{\begin{array}{l}
{\left[l_{x}^{2}\left(e_{x}^{2}-e_{x}^{1}\right)-l_{x+\mathrm{n}}^{2}\left(e_{x+\mathrm{n}}^{2}-e_{x+\mathrm{n}}^{1}\right)\right]-} \\
{\left[l_{x}^{1}\left(e_{x}^{1}-e_{x}^{2}\right)-l_{x+\mathrm{n}}^{1}\left(e_{x+\mathrm{n}}^{1}-e_{x+\mathrm{n}}^{2}\right)\right]}
\end{array}\right\}
$$

where $e_{x}^{t}$ is life expectancy at age $x$ and time $t, l_{x}{ }_{x}$ is the number of survivors at age $x$ and time $t$, and $n$ is the length of age interval.

A further decomposition by cause of death $(j)$ is performed:

$$
\varepsilon_{x, j}=\frac{M_{x, j}^{1}-M_{x, j}^{2}}{M_{x}^{1}-M_{x}^{2}} \times \varepsilon_{x}
$$

where $M_{x, j}$ is the age-specific mortality rate at age $x$, time $t$ and cause of death $j$ and $M^{t}$ is the overall age-specific mortality rate at age $x$ and time $t$.

\section{Results}

Figure 1 shows life expectancy at birth $\left(e_{0}\right)$ by sex, from 1940 to 2010 for the Southeast and Northeast regions. From 1940 to 1960, the difference between life expectancies in these two regions increased from 11.2 to 13.2 for males and from 7.5 to 9.8 years for females. This difference reduced significantly after 1960, but a new divergence emerged for males in the last period of analysis, when the difference in life expectancies at birth increased from 3.4 to 4.9 years.

Life expectancy at birth is often taken as an index of overall mortality, but gives a poor idea of lifespan, since it is heavily affected by infant mortality ${ }^{29}$. In order to make evident the regional differences in mortality without the effect of infant mortality, Figure 2 shows the life expectancy at age 10 $\left(e_{10}\right)$, by sex, for all regions, from 1980 to 2010 .

A convergence process in $e_{10}$ happened from 1980 to 2000 , which is shown by the narrowing difference in life expectancies between less developed regions (North and Northeast) and the more developed regions (South and Southeast). In the last decade, however, there was a divergence in adult mortality, much clearer for males than for females: the difference between the $e_{10}$ of the Southeast and Northeast regions increased in the last decade from 0.6 to 4.1 years for males and from 2.3 to 2.8 for females (Figure 2).

The $e_{10}$ of females for the South and Southeast regions have been presenting very similar patterns, whereas for males they have been significantly higher in the South region than for those in the Southeast, with a great divergence during the 1980s and 1990s. In the last decade, life expectancy for males in the Southeast has increased more than five years, leading to a new convergence between these regions (Figure 2).

Mortality trends for the Brazilian regions by sex, age, and cause of death were calculated to understand the reduction in regional differences from 1980 to 2000 and the recent divergence, especially 


\section{Figure 1}

Life expectancy at birth $\left(e_{0}\right)$ by sex. Southeast and Northeast regions, Brazil, 1940/2010.

1a) Male

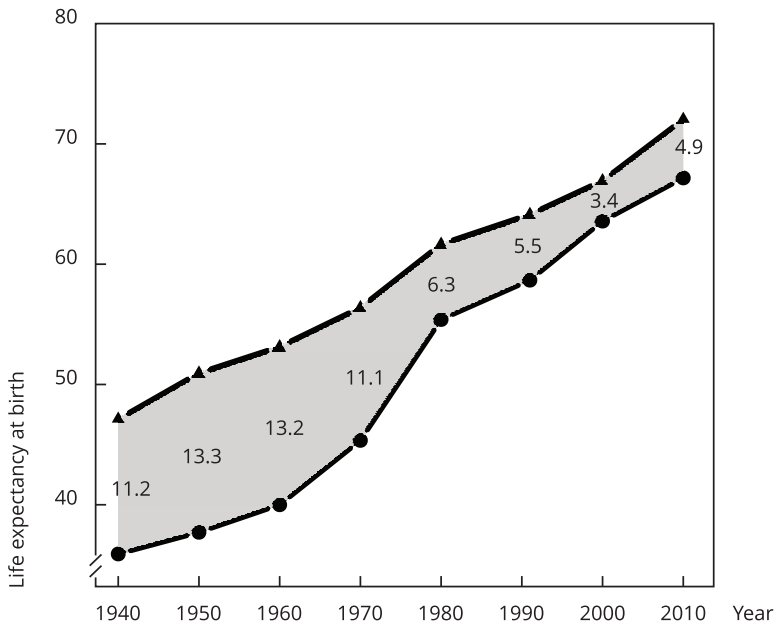

1b) Female

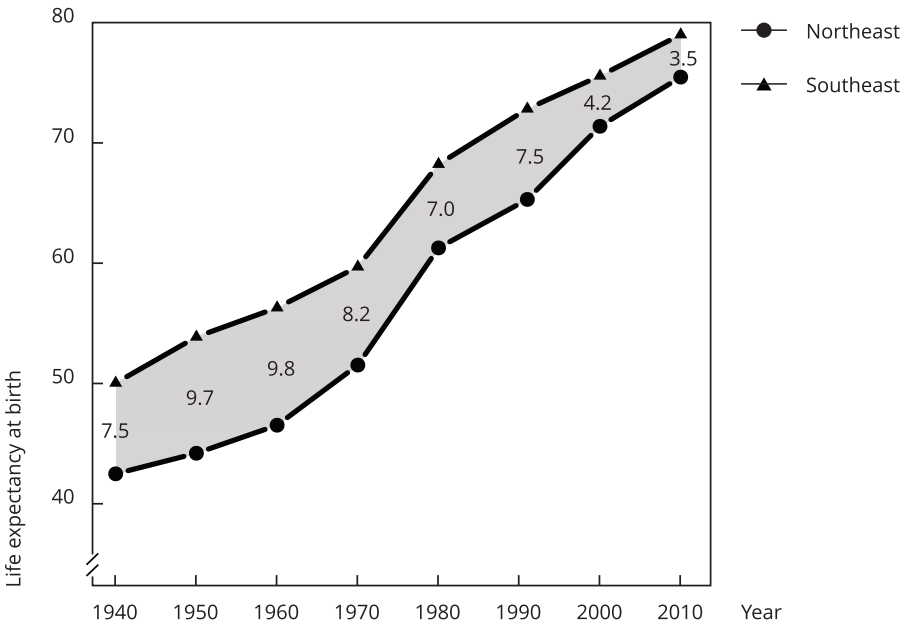

Sources: Simões 37, Albuquerque \& Senna 18, and Brazilian Institute of Geography and Statistics 6.

\section{Figure 2}

Life expectancy at age $10\left(e_{10}\right)$ by sex and major regions. Brazil, 1980/2010.

2a) Male

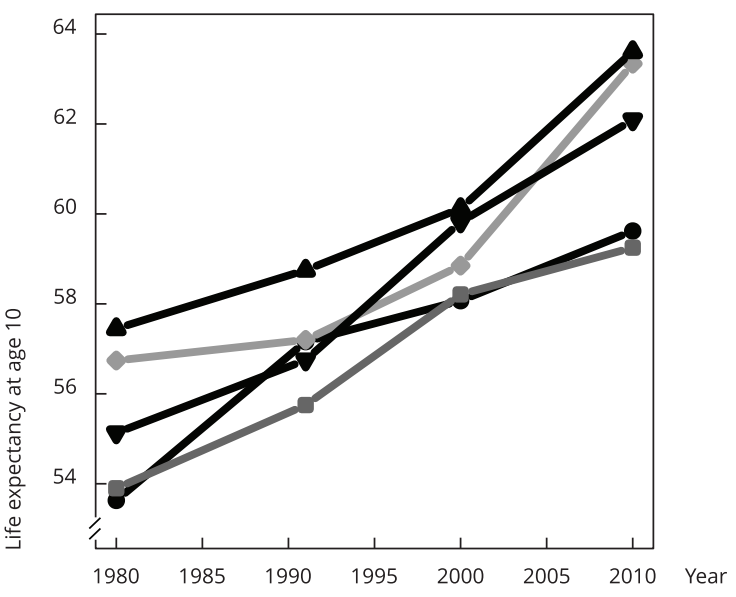

2b) Female

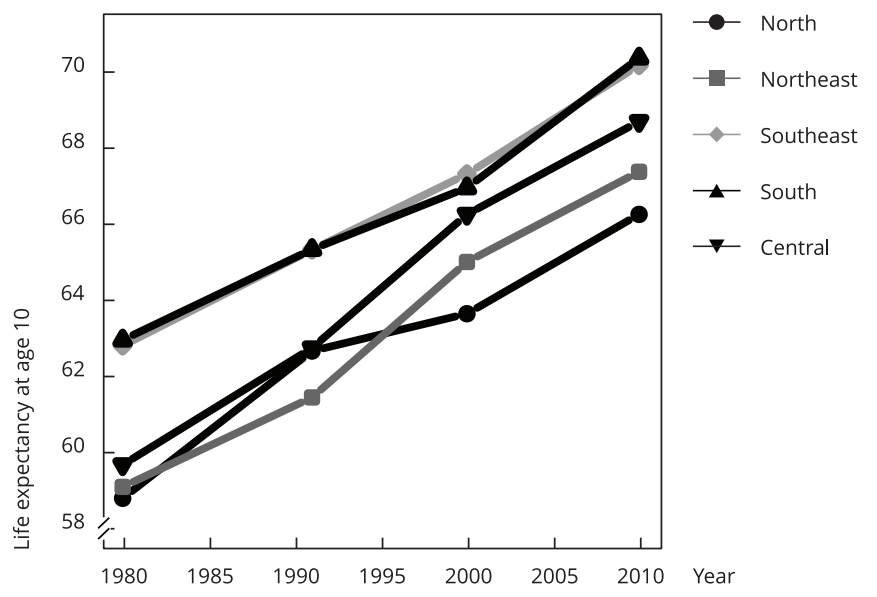

Sources: Albuquerque \& Senna 18 and Brazilian Institute of Geography and Statistics 6. 
for males. Figures 3 (males) and 4 (females) show the contribution to change in $e_{0}$ by age group and cause of death, according to major region, sex, and period under analysis.

The increase in life expectancy during the 1980s in Brazil was largely due to the decline of infant mortality, which accounted for 1.6 years of the total gains of 2.9 and 4.3 for males and females, respectively. Infectious and parasitic diseases, represented in large part by intestinal infectious diseases (Brazilian Health Informatics Department. http://tabnet.datasus.gov.br/cgi/tabcgi.exe?sim/cnv/obt10uf. def, accessed on 15/May/2015), explained almost 50\% of the gain in life expectancy due to mortality decline in the first age group. Despite the decreasing contribution of infant mortality in changes in $e_{0}$ over time, this is still an important cause of death among Brazilian children and its reduction remains important in explaining overall mortality decline. The most recent decline in mortality below one is due especially to certain conditions originating in the perinatal period (Figures 3 and 4), primarily regarding respiratory and cardiovascular disorders (Brazilian Health Informatics Department. http:// tabnet.datasus.gov.br/cgi/tabcgi.exe?sim/cnv/obt10uf.def, accessed on 15/May/2015).

From 1980 to 1991 , mortality growth among young adult males from 15 to 34 years old, mostly due to external causes, had a negative impact on life expectancy at birth (Figure 3). In 1991, around $1 / 4$ of the deaths due to external causes among young males was attributable to transport accidents and around 40\% to homicides (Brazilian Health Informatics Department. http://tabnet.datasus.gov. br/cgi/tabcgi.exe?sim/cnv/obt10uf.def, accessed on 15/May/2015). Mortality declined slightly in this age group during the periods of 1991-2000 and 2000-2010, contributing only 0.3 years to the increase in $e_{0}$ in each period (Figure 3). In 2010, 28\% of the deaths from external causes among young males were due to transport accidents and the participation of homicides rose to more than 50\% (Brazilian Health Informatics Department. http://tabnet.datasus.gov.br/cgi/tabcgi.exe?sim/cnv/obt10uf.def, accessed on 15/May/2015). Mortality decline for females in the same age groups has also made only a minor contribution to the overall increase in life expectancy (Figure 4).

Mortality change among middle-age adult males (35-59) had important contributions to life expectancy increase, especially in the last two decades - 0.9 and 1.0 year, respectively, for the periods of 1991-2000 and 2000-2010. For females, the gains in life expectancy at birth due to mortality decline in this age group have been also significant and more constant over time, representing 0.7 year in each period. These trends were mostly driven by the decline in mortality from diseases of the circulatory system, as shown in Figures 3 and 4.

There have also been important contributions to increases in life expectancy at birth due to a decline in mortality from cardiovascular diseases among the older adult population (aged 60 or older). These improvements were higher for women and, along with the difference in mortality from external causes, help to explain the long-term widening of the gender gap in life expectancy (Figures 3 and 4).

Analyzing each region separately helps understanding the health transition processes for the country as a whole, since they present different timings and, from time to time, contrasting trends.

The Southeast and South regions present very similar trends for females, represented by a decrease in the role of infant mortality in overall mortality improvement and a shift from a predominance of infectious and parasitic diseases to diseases related to the perinatal period. Decline in deaths from cardiovascular diseases has been the main driver for the mortality decline at older ages for women in these two regions, but the share of mortality attributable to cancer gained importance in the last decade. Respiratory diseases have also contributed to increasing life expectancy, especially in the older adults group (Figure 4).

The same general trends described for women can also be observed for men (Figure 3). However, some important differences help to explain the process of divergence/convergence between these two regions in the last 30 years, as showed in Figure 2. From 1980 to 1991, there was an important increase in mortality among males at ages 15 to 45 years in the Southeast 18 , which contributed negatively to the decline in life expectancy at birth. This was largely due to mortality from external causes, especially for ages 15-29 years (Figure 3).

Furthermore, negative contributions from "other causes" emerged at ages 25-39, which are largely represented by deaths related to HIV/AIDS (Figure 3). In the ICD-9, HIV/AIDS was classified in category 279 (disorders involving the immune mechanism), within Chapter 4 (endocrine, nutritional and metabolic diseases, and immunity disorders). Almost $80 \%$ of the deaths in Chapter 4 among 
Figure 3

Contribution to change in $e_{0}$ by age group and cause of death. Males from Southeast, South and Central regions, Brazil, 1980-1991, 1991-2000, and 2000-2010.

3a) Brazil, 1980-1991

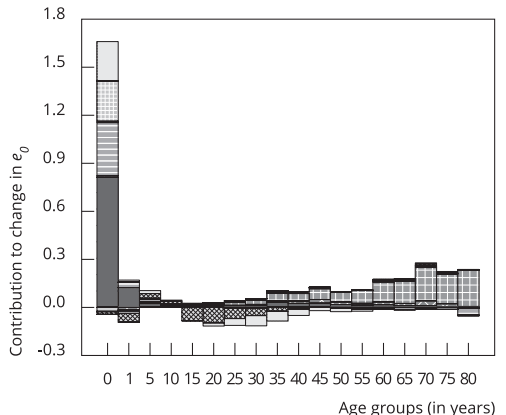

3d) Southeast, 1980-1991

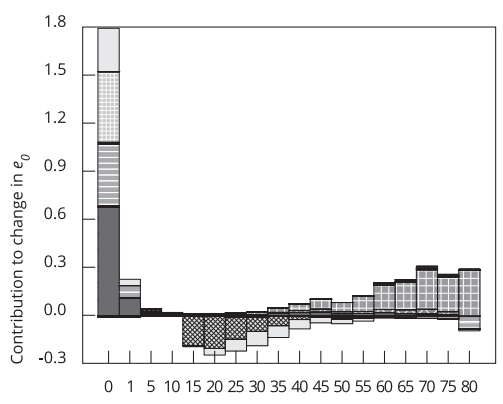

Age groups (in years)

3g) South, 1980-1991

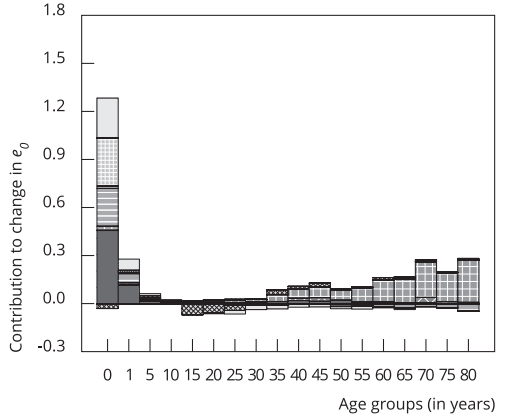

3j) Central, 1980-1991

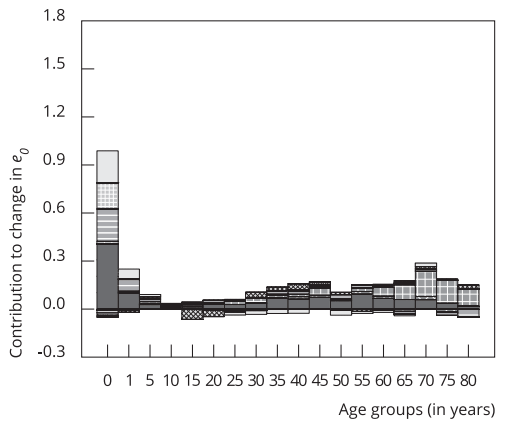

Age groups (in years) 3b) Brazil, 1991-2000

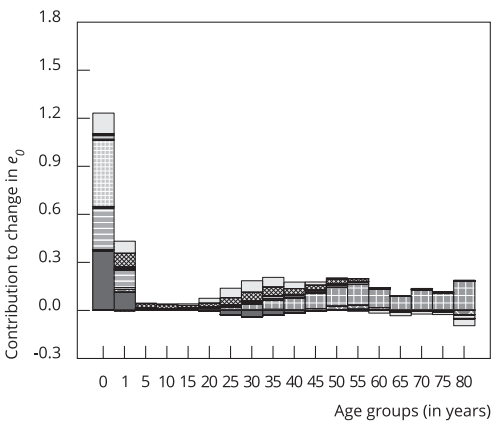

3e) Southeast, 1991-2000

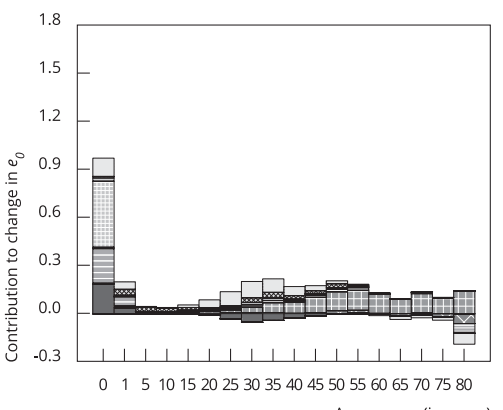

Age groups (in years)

3h) South, 1991-2000

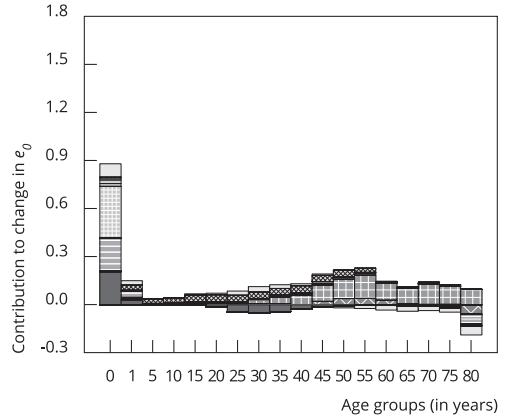

3k) Central, 1991-2000

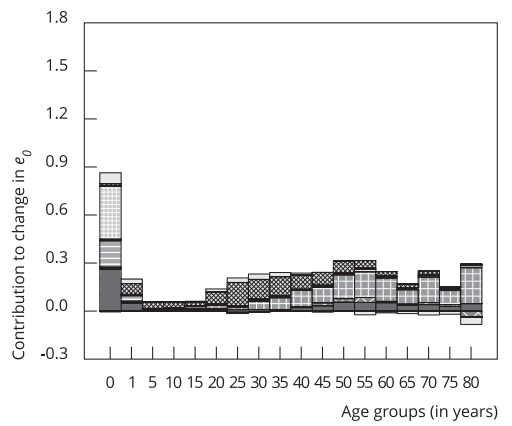

3c) Brazil, 2000-2010

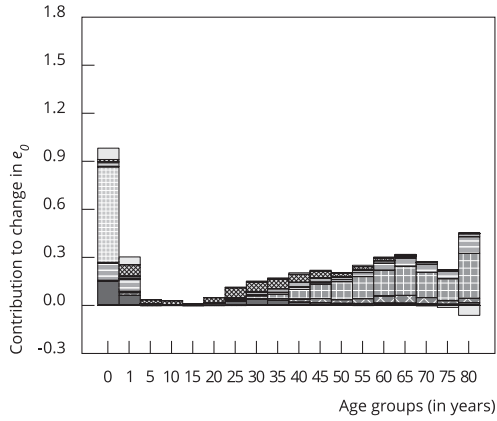

3f) Southeast, 2000-2010

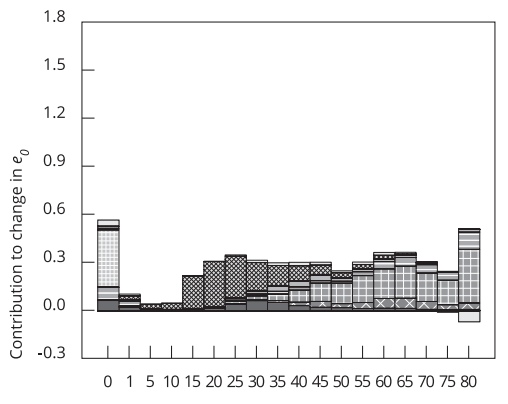

Age groups (in years)

3i) South, 2000-2010

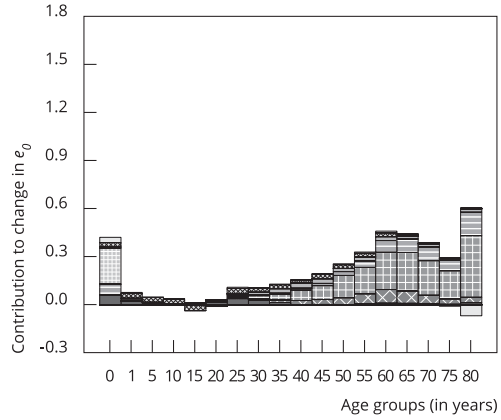

31) Central, 2000-2010

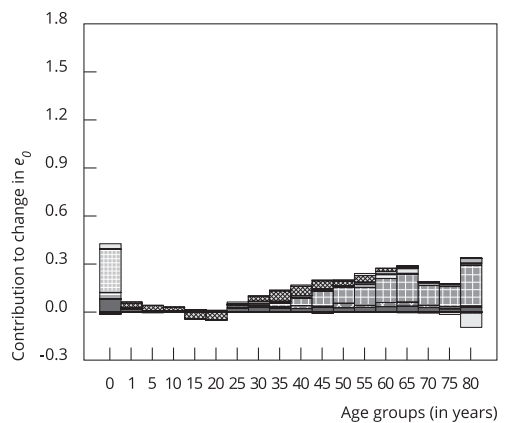

Age groups (in years)
IPD

NEO

国 DCC

自 DRS

DDS

PII PER

CON

EXT

$\sqcap$ OTH

CON: congenital affections; DCC: diseases of the circulatory system; DDS: diseases of the digestive system; DRS: diseases of the respiratory system; EXT: external causes; IPD: infectious and parasitic diseases; NEO: neoplasms; OTH: others; PER: perinatal affections.

Sources: Albuquerque \& Senna 18, Brazilian Institute of Geography and Statistics 6, and Brazilian Health Informatics Department

(http://tabnet.datasus.gov.br/cgi/tabcgi.exe?sim/cnv/obt10uf.def, accessed on 15/May/2015). 
Figure 4

Contribution to change in $e_{0}$ by age group and cause of death. Females from Southeast, South and Central regions, Brazil, 1980-1991, 1991-2000, and 2000-2010.

4a) Brazil, 1980-1991

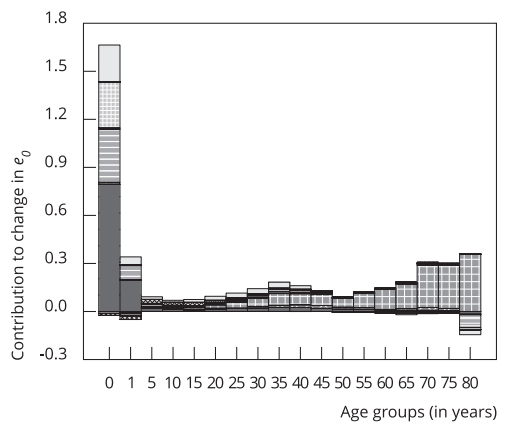

4d) Southeast, 1980-1991

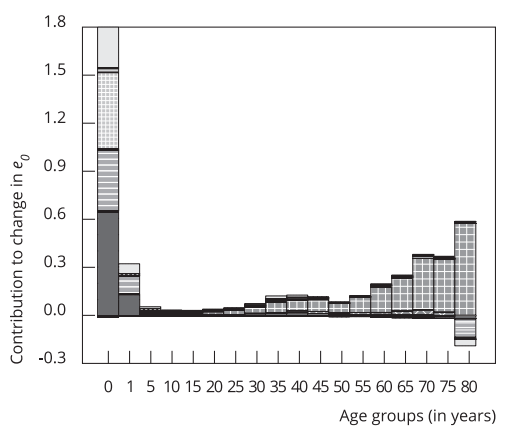

4g) South, 1980-1991

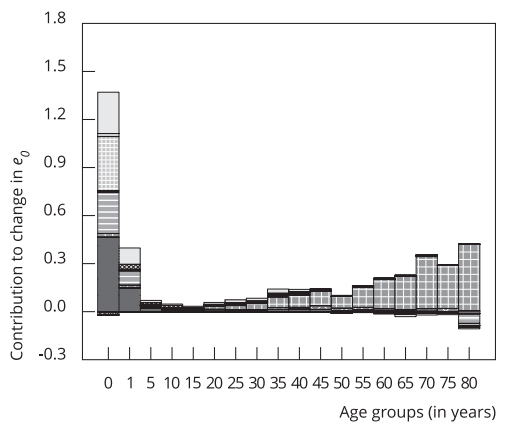

4j) Central, 1980-1991

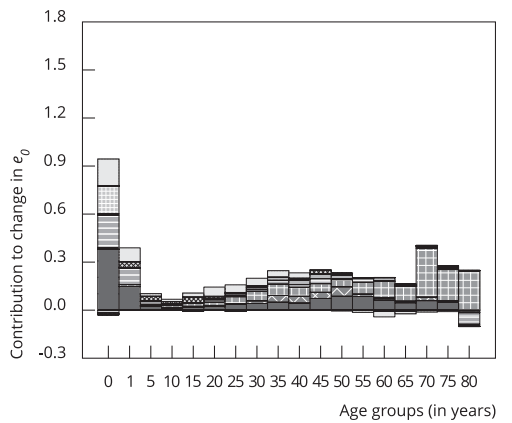

4b) Brazil, 1991-2000

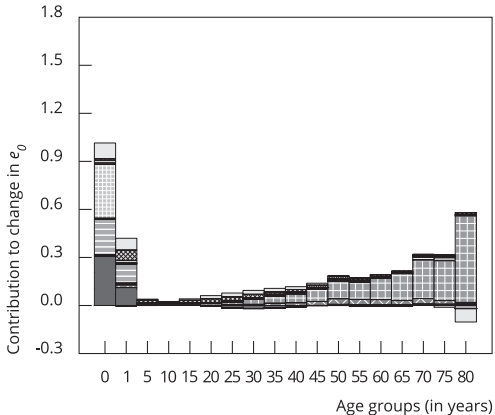

4e) Southeast, $1991-2000$

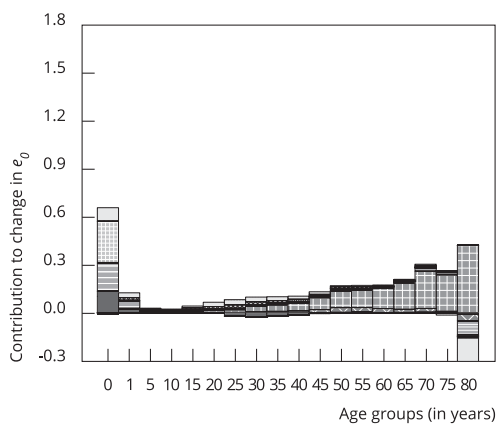

4h) South, $1991-2000$

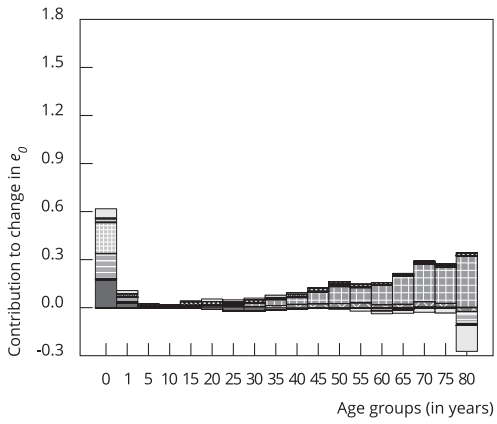

4k) Central, 1991-2000

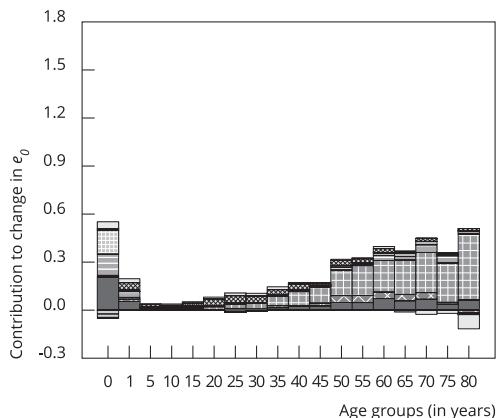

4c) Brazil, 2000-2010

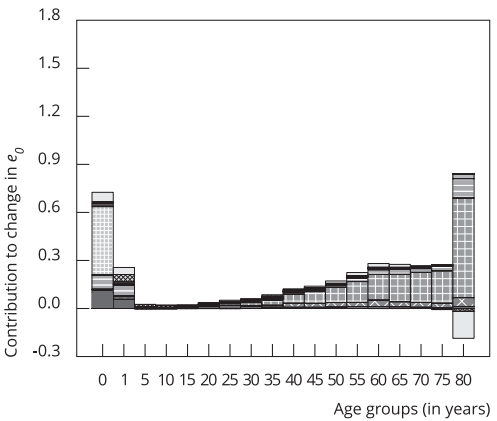

4f) Southeast, $2000-2010$

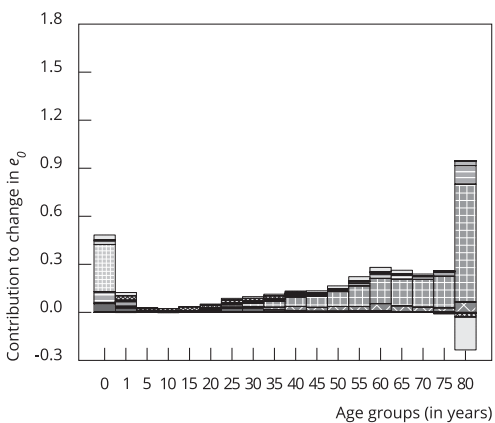

4i) South, 2000-2010

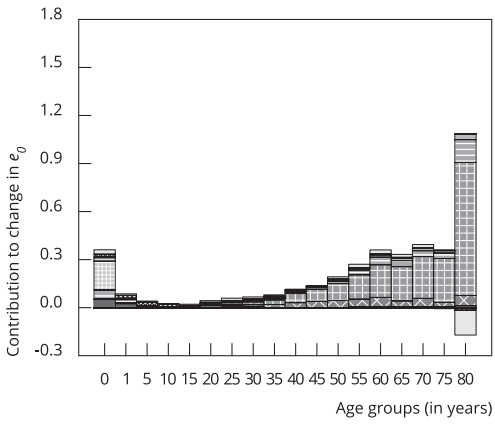

4l) Central, 2000-2010

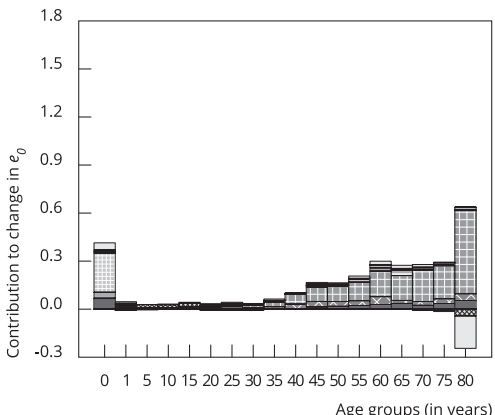

IPD

NEO

罯 DCC

貝 DRS

DDS

PER

自 CON

EXT

| OTH

CON: congenital affections; DCC: diseases of the circulatory system; DDS: diseases of the digestive system; DRS: diseases of the respiratory system; EXT: external causes; IPD: infectious and parasitic diseases; NEO: neoplasms; OTH: others; PER: perinatal affections.

Sources: Albuquerque \& Senna 18, Brazilian Institute of Geography and Statistics 6, and Brazilian Health Informatics Department

(http://tabnet.datasus.gov.br/cgi/tabcgi.exe?sim/cnv/obt10uf.def, accessed on 15/May/2015). 
young adult males in Southeast region in 1991 were classified in this category (Brazilian Health Informatics Department. http://tabnet.datasus.gov.br/cgi/tabcgi.exe?sim/cnv/obt10uf.def, accessed on 15/May/2015). It is well known that from the beginning of the HIV/AIDS epidemic, the Southeast region showed the highest concentration of cases and also stood out for higher mortality from this disease 30,31 .

In the last decade, however, the Southeast region presented an incredible decline in mortality from external causes (Figure 3).

The main difference between the Central region and the national average is the mortality from infectious and parasitic diseases among adults, which had an important contribution to the increase in life expectancy (Figures 3 and 4). Most of the adult mortality decline from infectious and parasitic diseases in the Central region was due to trypanosomiasis or Chagas' disease, which was a particularly important cause of death in the states of Goiás and Federal District, where, in 1980, more than 70\% of the deaths from infectious and parasitic diseases had trypanosomiasis as the main cause (Brazilian Health Informatics Department. http://tabnet.datasus.gov.br/cgi/tabcgi.exe?sim/cnv/obt10uf.def, accessed on 15/May/2015).

Due to the high proportion of ill-defined causes, changes in life expectancy in the North and Northeast regions were decomposed only into age groups (Figure 5). Even though some bias could result from the large proportion of under-registered deaths and the inability of indirect techniques to correct the lack of information, it is possible to infer general mortality trends for these regions.

Declines in infant mortality have been responsible for an increase in life expectancy of more than 1.5 years per decade in the Northeast, accounting for a large part of the increase in life expectancy in this region even for recent periods (Figure 5).

In general, females in the Northeast region showed larger gains in life expectancy than males, contributing to the increase in the sex gap in mortality, from 5.9 years in 1980 to 8.3 years in 2010 . This region had the largest $e_{0}$ difference between the two sexes in 2010 18,19. Most of this difference is due to higher young adult male mortality from external causes. In addition, this gender gap in life expectancy reflects differences in mortality due to chronic diseases at older ages 19.

Increase in life expectancy in the North region is also largely attributable to infant mortality decline, though not to the same extent as in the Northeast region (Figure 5).

Mortality decline among women of reproductive age also contributed significantly to increasing female life expectancy from 1980 to 1991 (Figure 5). An important share of this decline can be attributable to improvements in maternal mortality. In 1980, 22\% of deaths registered among women aged from 15 to 39 years were due to "complications of pregnancy, childbirth, and puerperium", significantly higher than the 8.3\% observed in 1991 (Brazilian Health Informatics Department. http:// tabnet.datasus.gov.br/cgi/tabcgi.exe?sim/cnv/obt10uf.def, accessed on 15/May/2015).

The negative contribution to life expectancy of mortality in young adult males in the period of 2000-2010 is also worth noting, while advanced ages contributed positively (Figure 5).

\section{Discussion and conclusions}

The purpose of this study was to examine the Brazilian health transition by describing the regional variations in health and explaining the divergence/convergence processes in life expectancy according to changes in mortality by sex, age groups, and causes of death. Despite some limitations in the raw data and in the procedures used to correct underreported deaths and ill-defined causes, these statistics, as claimed by Laurenti et al. 32 , have been important instruments for epidemiological analysis and, even though there could be some biases, general trends appear to be fairly reliable.

In addition to coverage limitations in the raw data, there are other sources of errors, such as inaccuracy of diagnosis on death certificates. Overdiagnosis of deaths resulting from cardiovascular causes, for example, is a problem in developed countries, and are likely to happen in developing countries as well 33. Thus, part of the decline in mortality from cardiovascular diseases could reflect improvements in mortality data quality, for instance, due to early diagnosis. However, the remarkable decline in mortality from cardiovascular diseases that took place in many parts of the world 34,35 is also likely to have happened in Brazil. 
Figure 5

Contribution to change in $e_{0}$ by age group. North and Northeast regions, Brazil, 1980-1991, 1991-2000, and 2000-2010.

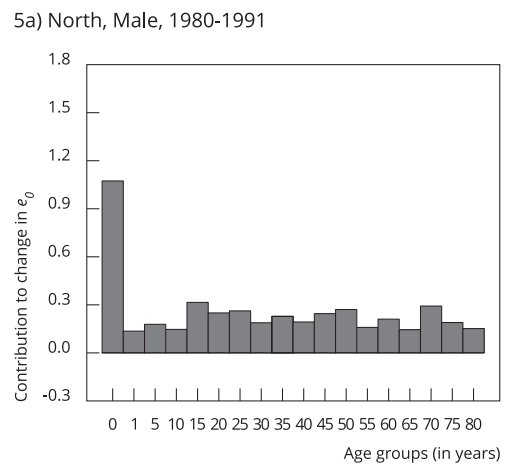

5d) North, Female, 1980-1991

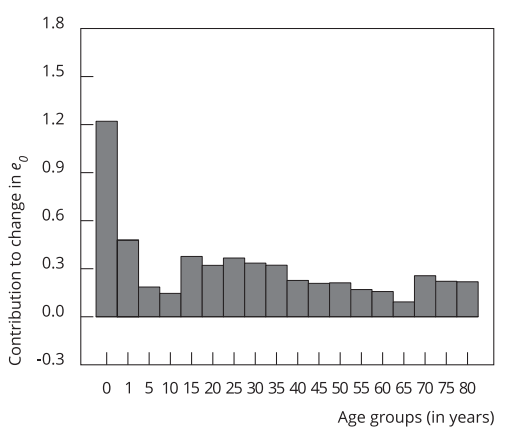

5g) Northeast, Male, 1980-1991

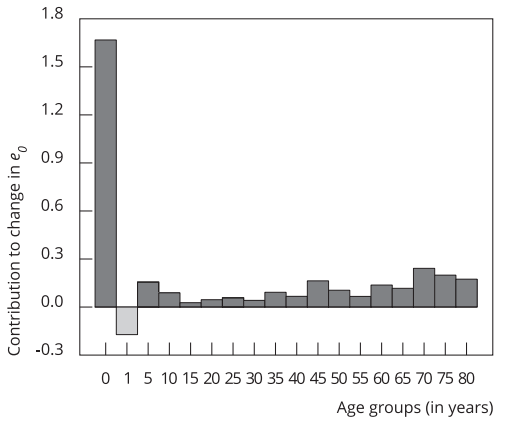

5j) Northeast, Female, 1980-1991

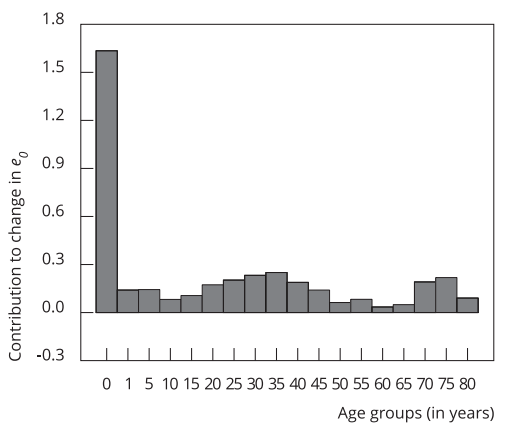

5b) North, Male, 1991-2000

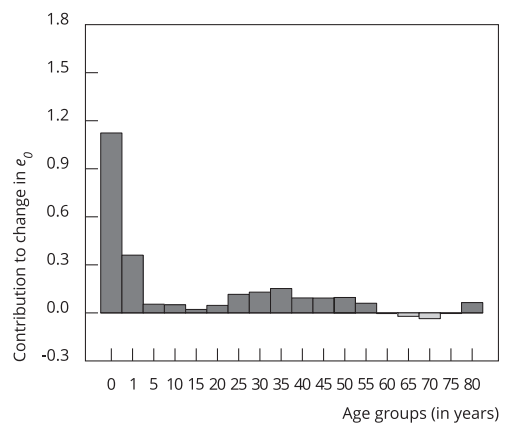

5e) North, Female, 1991-2000

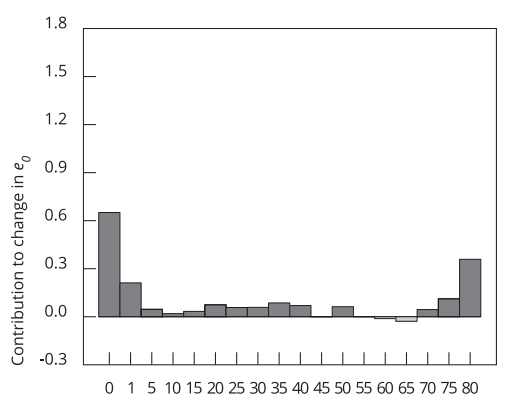

Age groups (in years)

5h) Northeast, Male, 1991-2000

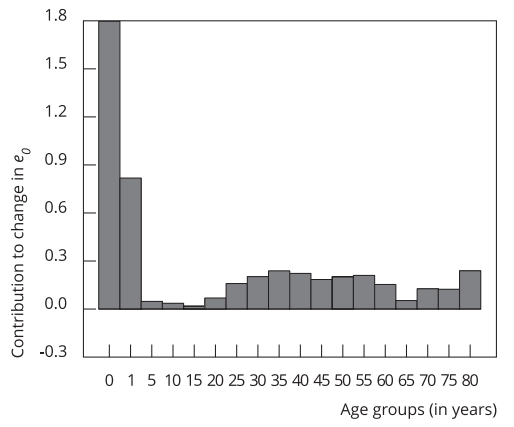

5k) Northeast, Female, 1991-2000

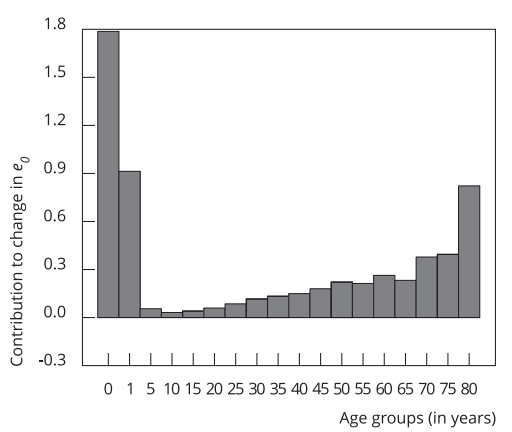

5c) North, Male, 2000-2010

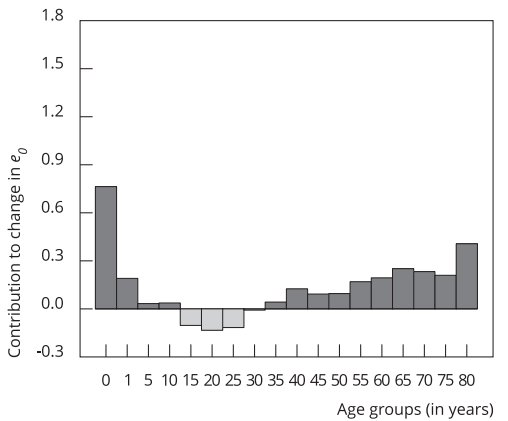

5f) North, Female, 2000-2010

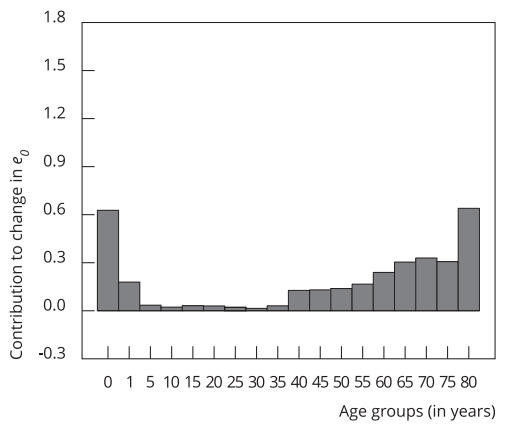

5i) Northeast, Male, 2000-2010

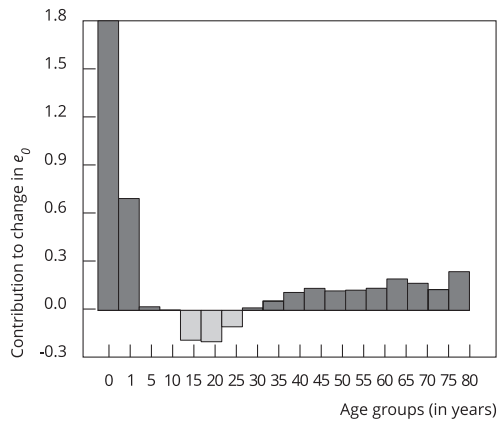

5I) Northeast, Female, 2000-2010

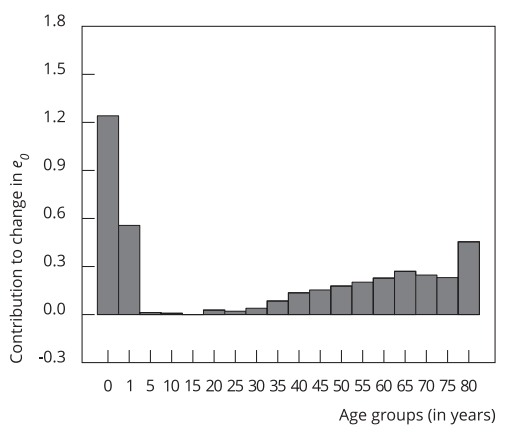

CON: congenital affections; DCC: diseases of the circulatory system; DDS: diseases of the digestive system; DRS: diseases of the respiratory system; EXT: external causes; IPD: infectious and parasitic diseases; NEO: neoplasms; OTH: others; PER: perinatal affections.

Sources: Albuquerque \& Senna 18, Brazilian Institute of Geography and Statistics 6, and Brazilian Health Informatics Department

(http://tabnet.datasus.gov.br/cgi/tabcgi.exe?sim/cnv/obt10uf.def, accessed on 15/May/2015). 
It has been shown that life expectancy in Brazilian regions, notwithstanding the long-term convergence trend, have also presented periods of divergence, reflecting socioeconomic and regional inequalities in the country.

Life expectancy has increased substantially in Brazil since the 1930s, presenting more rapid improvements than those observed in the European countries when they had the same mortality levels. However, there have been persistent regional inequalities, even though the long-term trends show reducing differences. In the 1930s, life expectancy in the South region was around 50 years, 15 years higher than for the Northeast region 36. Between 1940 and 1960, the difference of life expectancy in the Southeast and Northeast increased as a result of the health policy model that followed the profound social stratification in the country, prioritizing the more developed regions, already engaged in the new dynamic of the expanding labor market. From the mid-1970s there was an acceleration of mortality decline, driven by the decline in infant mortality. These changes were the consequence of governmental action, such as the generalization of health and sanitation services and immunization, leading to a reduction in regional inequalities in mortality 37 . New convergence in the regional life expectancy rises as a result of the expansion and decentralization of health and sanitation services, offering these services to areas excluded in the past 38 .

Decline in infant and child mortality has been historically the main driver of changes in life expectancy, contributing largely to explain regional variations in mortality. In the last decades, however, when infant and child mortality have achieved considerable lower levels, and improvements in access to health, behavioral, and socioeconomic factors have taken place, mortality decline among adults and older adults has emerged as an important factor in explaining overall life expectancy variations.

Mortality changes in Brazil have followed the epidemiologic transition theory to some extent during the period under analysis: the sharp decline in infant mortality in all regions (first from infectious and parasitic diseases and then from causes associated to the perinatal period); maternal mortality decline in the 1980s in the North region; reduction in mortality from Chagas' disease in the Central; and increase in the participation of chronic and degenerative diseases as the main cause of death.

However, this study has showed that the epidemiologic transition in Brazil has not followed the linear and unidirectional pattern observed in many developed countries, requiring a broader framework to understand health transition in the country, with particular attention to social and regional inequalities.

The emergence of the HIV/AIDS epidemic, for example, is considered the most important fact in questioning the basis of the epidemiologic transition, which does not allow for the establishment of the emerging and re-emerging infectious diseases. Even though the HIV/AIDS epidemic has never been as prevalent as in some other countries, it had significant negative effects on life expectancy at birth in Brazil, especially among males in the Southeast region.

The persistence of relatively high levels of other infectious and parasitic diseases, even more than 70 years after the beginning of substantial mortality decline, is also a particularity of the Brazilian health transition. Despite important decline in mortality from infectious and parasitic diseases, morbidity has exhibited a different trend, with the percentage of hospitalizations from these causes presenting almost constant figures for the last three decades: around 8\%, with some seasonal fluctuations, according to data from the Hospital Information System of the Brazilian Ministry of Health (SIH/SUS). The persistence of these diseases involves economic and social burdens, with direct and indirect costs to society. The simplified view of the epidemiologic transition could have even contributed to the unpreparedness of health services and workers, as well as the society as a whole, in facing the emergence and reemergence of infectious diseases 16.

Another missing aspect in the epidemiologic transition theory is the unexpected improvement in mortality from cardiovascular diseases. Just as observed in many other developed countries 39, improvements in mortality from this cause of death have been the main driver of mortality decline for older adults, although it has been unequal according to the different regions. This inequality could be attributable to differences in socioeconomic status and lifestyle. Growing evidences have shown that several changes in cardiovascular risk factors are associated with their health impact. In fact, among the five most important causes of ill health and premature death in Latin America are smoking, hypertension, diabetes, obesity, and physical inactivity 40. 
Malta et al. 41 attribute the decline in mortality from cardiovascular diseases and general chronic non-communicable diseases in Brazil to improvements in access to health services, the noticeable decline in smoking, as well as improvements in socioeconomic conditions. Early life conditions might also have affected childhood differently in the regions. Oliveira et al. 42 claim, for example, that the historical decline in cardiovascular mortality in Brazil is more related to declining exposure to infectious agents, particularly early in life, due to improvements in the living conditions of the population than to the control of biological risk factors or to technological advances in clinical practice.

Mortality decline due to neoplasia has contributed to increasing life expectancy, though to a much lower extent than circulatory diseases. Malta et al. 41 pointed out that the trend in cancer mortality varies depending on sex, age, and location. In fact, this study's results have shown important regional inequalities in mortality decline from cancer, since it has gained importance in the last decade in the more developed regions, whereas mortality reduction from this disease in the less developed regions had only minor contribution to the increase in life expectancy.

Finally, the key factor contributing negatively to the increase of life expectancy is mortality from external causes, especially among young adult males. This impact has varied significantly over time and across regions, being the most important cause of the historical divergence/convergence process among the Brazilian regions. The contrasting trends in mortality among adult males in the Southeast and Northeast in the last decade is a clear example. São Paulo and Rio de Janeiro, in the Southeast region, were the two states that presented the largest decline in mortality from external causes in Brazil during this period, mostly because of a decline in homicide rates, resulting from the impact of disarmament strategies and policies addressing violence. On the other hand, almost all the states in the Northeast region presented an important increase in homicide rates in the last decade 43 .

These findings have shown that the idea of convergence, implicit to the demographic and epidemiologic transition theories, might not apply to the Brazilian case during the period under study. Despite some long-term trends showing reducing regional inequalities, there have been some periods of divergence in life expectancy at different ages, for instance, among the Southeast and the North and Northeast regions.

The interruption of the long-term convergence in mortality after the year of 2000, especially among males, might be merely a temporary phenomenon - as often occurs in divergence/convergence processes -, to be confirmed in the next years, when new data become available. However, a new mortality convergence process among the less and more developed regions in the future would only be possible if the North and Northeast regions could sustain the important declines in infant mortality observed in the last decades and if mortality among young adult males could be better controlled. Furthermore, differences in mortality among older adults persist, for both males and females: in 2010, life expectancies at age $60\left(e_{60}\right)$ in the South and Southeast regions were still higher than in those in the North and Northeast 19. Thus, future trends in regional inequalities in mortality will also depend on the ability of each region to incorporate the benefits of new technologies to treatment and, most importantly, to improve prevention, especially against cardiovascular diseases. Controlling risk factors of these diseases is also a key point to control mortality from chronic and degenerative diseases. 


\section{Acknowledgments}

This study was partially supported by Capes/Brazil. I would also like to thank Magali Barbieri (Institut National d'Études Démographiques and University of California, Berkeley) for her comments, which greatly improved the manuscript.

\section{References}

1. Omran AR. The epidemiologic transition: a theory of the epidemiology of population change. Milbank Mem Fund Q 1971; 49:509-38.

2. Omran AR. Epidemiologic transition. In: Ross JA, editor. International encyclopedia of population. New York: The Free Press; 1982. p. 172-5.

3. Olshansky SJ, Ault AB. The fourth stage of the epidemiologic transition: the age of delayed degenerative diseases. Milbank Q 1986; 64:355-91.

4. Omran AR. The epidemiologic transition theory revisited thirty years later. World Health Stat Q 1998; 51:99-119.

5. Coleman DA. Populations of the industrial world: a convergent demographic community? Int J Popul Geogr 2002; 8:319-44.

6. Instituto Brasileiro de Geografia e Estatística. Projeções da população: Brasil e Unidades da Federação. Rio de Janeiro: Instituto Brasileiro de Geografia e Estatística; 2013. (Série Relatórios Metodológicos, 40).

7. Vallin J, Meslé F. Convergences and divergences in mortality. A new approach to health transition. Demogr Res 2004; 2:10-43.

8. Lerner M. Modernization and health: a model of the health transition. In: Annual Meeting of the American Public Health Association. San Francisco: American Public Health Association; 1973.

9. Frenk J, Bobadilla JL, Stern C, Frejka T, Lozano R. Elements for a theory of the health transition. Health Transit Rev 1991; 1:21-38.

10. Palloni A, Pinto-Aguirre G. Adult mortality in Latin America and the Caribbean. In: Rogers RG, Crimmins EM, editors. International handbook of adult mortality. Amsterdam: Springer; 2011. p. 101-32.

11. Atun R, De Andrade LOM, Almeida G, Cotlear D, Dmytraczenko T, Frenz P, et al. Health-system reform and universal health coverage in Latin America. Lancet 2015; 385:1230-47.

12. Frejka T, Bobadilla JL, Stern C, Lozano R, Sepúlveda J, José M. La transición epidemiológica en América Latina. Bol Oficina Sanit Panam 1991; 111:485-96.

13. Schramm JMA, Oliveira AF, Leite IC, Valente JG, Gadelha ÂMJ, Portela MC, et al. Transição epidemiológica e o estudo de carga de doença no Brasil. Ciênc Saúde Coletiva 2004; 9:897908.

14. Teixeira MG, Meyer MA, Costa MCN, Paim JS, Silva LMV. Mortality due to infectious and parasitic diseases in Salvador, Bahia: evolution and intra-urban differences according to living conditions. Rev Soc Bras Med Trop 2002; 35:491-7.

15. Campelo V, Gonçalves MAG, Donadi EA. Mortality due to infectious and parasitic diseases in the city of Teresina - PI (Brazil), 19712000. Rev Bras Epidemiol 2005; 8:31-40.

16. Luna EJA. A emergência das doenças emergentes e as doenças infecciosas emergentes e reemergentes no Brasil. Rev Bras Epidemiol 2002; 5:229-43. 
17. Gawryszewski VP, Koizumi MS, Mello-Jorge MHP. Morbidity and mortality from external causes in Brazil, 2000. Cad Saúde Pública 2004; 20:995-1003.

18. Albuquerque F, Senna J. Tábuas de mortalidade por sexo e grupos de idade: Grandes Regiões e Unidades da Federação de 1980, 1991 e 2000. Rio de Janeiro: Instituto Brasileiro de Geografia e Estatística; 2005.

19. Instituto Brasileiro de Geografia e Estatística. Projeção da população das Unidades da Federação por sexo e idade: 2000-2030. http://www.ibge.gov.br/home/estatistica/ populacao/projecao_da_populacao/2013/ (accessed on 15/May/2015).

20. Brass W, Coale AJ, Demeny P, Heisel DF, Lorimer F, Romaniuk A, et al. The demography of tropical Africa. Princeton: Princeton University Press; 1968.

21. Trussell TJ. A re-estimation of the multiplying factors for the Brass technique for determining childhood survivorship rates. Popul Stud (Camb) 1975; 29:97-107.

22. Brass W. Methods for estimating fertility and mortality from limited and defective data. Chapel Hill: University of North Carolina; 1975.

23. Courbage Y, Fargues P. A method for deriving mortality estimates from incomplete vital statistics. Popul Stud (Camb) 1979; 33:165-80.

24. Preston S, Coale AJ, Trussell J, Weinstein M. Estimating the completeness of reporting of adult deaths in populations that are approximately stable. Popul Index 1980; 46:179-202.

25. Jorge MHPM, Gotlieb SLD, Laurenti R. The national mortality information system: problems and proposals for solving them. I - deaths by natural causes. Rev Bras Epidemiol 2002; 5:197-211.

26. França E, Teixeira R, Ishitani L, Duncan BB, Cortez-Escalante JJ, Morais Neto OL, et al. Causas mal definidas de óbito no Brasil: método de redistribuição baseado na investigação do óbito. Rev Saúde Pública 2014; 48:671-81.

27. Mathers CD, Ma Fat D, Inoue M, Rao C, Lopez AD. Counting the dead and what they died from: an assessment of the global status of cause of death data. Bull World Health Organ 2005; 83:171-7.

28. Shkolnikov V, Valkonen T, Begun A, Andreev E. Measuring inter-group inequalities in length of life. Genus 2001; 57:33-62.

29. Wachter KW. Essential demographic methods. Cambridge: Harvard University Press; 2014.

30. Dhalia C, Barreira D, Castilho E. A AIDS no Brasil: situação atual e tendências. Bol Epidemiol AIDS 2000; 13:3-13.
31. Reis AC, Santos EM, Cruz MM. A mortalidade por aids no Brasil: um estudo exploratório de sua evolução temporal. Epidemiol Serv Saúde 2007; 16:195-205.

32. Laurenti R, Jorge M, Gotlieb SLD. The accuracy of the official mortality and morbidity statistics related to chronic non-communicable diseases. Ciênc Saúde Coletiva 2004; 9:909-20.

33. Pagidipati NJ, Gaziano TA. Estimating deaths from cardiovascular disease: a review of global methodologies of mortality measurement. Circulation 2013; 127:749-56.

34. Uemura K, Pisa Z. Trends in cardiovascular disease mortality in industrialized countries since 1950. World Health Stat Q 1988; 41:155-78.

35. Levi F, Lucchini F, Negri E, Vecchia CL. Trends in mortality from cardiovascular and cerebrovascular diseases in Europe and other areas of the world. Heart 2002; 88:119-24.

36. Carvalho JAM. Evolução demográfica recente no Brasil. Pesquisa e Planejamento Econômico 1980; 10:527-54.

37. Simões CCS. Perfis de saúde e de mortalidade no Brasil: uma análise de seus condicionantes em grupos populacionais específicos. Brasília: Organização Pan-Americana da Saúde/Organização Mundial da Saúde; 2001.

38. Simões CCS, Oliveira LAP. O processo demográfico brasileiro. In: Diretoria de Geociências, Instituto Brasileiro de Geografia e Estatística, organizador. Atlas Nacional do Brasil Milton Santos. Rio de Janeiro: Instituto Brasileiro de Geografia e Estatística; 2010. p. 113-41.

39. Vallin J, Meslé F. Convergences and divergences in mortality: a new approach to health transition. Demogr Res 2004; 2:10-43.

40. Pramparo P, Montano CM, Barceló A, Avezum A, Wilks R. Cardiovascular diseases in Latin America and the Caribbean: the present situation. Prev Control 2006; 2:149-57.

41. Malta DC, Moura L, Prado RR, Escalante JC, Schmidt MI, Duncan BB. Mortalidade por doenças crônicas não transmissíveis no Brasil e suas regiões, 2000 a 2011. Epidemiol Serv Saúde 2014; 23:599-608.

42. Oliveira GMM, Klein CH, Souza e Silva NA. Mortality from cardiovascular diseases in three Brazilian states from 1980 through 2002. Rev Panam Salud Pública 2006; 19:85-93.

43. Waiselfisz JJ. Mapa da violência 2013: homicídios e juventude no Brasil. Brasília: SecretariaGeral da Presidência da República; 2013. 


\section{Resumo}

$O$ estudo analisa as principais características da transição da saúde no Brasil como um todo e nas cinco macrorregiões, utilizando um referencial que leva em conta as desigualdades regionais nas tendências de mortalidade. $\mathrm{O}$ artigo descreve e discute o processo de divergência/convergência regional da mortalidade, ao considerar as contribuições específicas dos grupos etários e as causas de óbito para as variações na expectativa de vida. De acordo com os resultados, em certa medida a mudança na mortalidade no Brasil segue a teoria da transição epidemiológica durante o período de estudo - por exemplo, com a importante queda na mortalidade infantil em todas as regiões do Brasil (primeiro pelas doenças infecto-parasitárias, e depois pelas causas associadas ao período perinatal) e o aumento da participação das doenças crônicas e degenerativas como a principal causa de mortalidade. Entretanto, algumas características da transição brasileira não confirmaram o padrão linear e unidirecional proposto pela teoria da transição epidemiológica, o que ajuda a entender os períodos de divergência regional na expectativa de vida (apesar das tendências, no longo prazo, de redução das desigualdades regionais). Alguns exemplos incluem a epidemia de HIV/AIDS, a persistência de níveis relativamente altos de outras doenças infecciosas e parasitárias, as diferenças regionais na melhoria inesperada nas taxas de mortalidade por doenças cardiovasculares $e$ as variações rápidas $e$ acentuadas na mortalidade por causas externas.

Transição da Saúde; Causas de Morte; Análise Demográfica

\section{Resumen}

El estudio analiza las principales características de la transición de la salud en Brasil, como un todo y en las cinco macrorregiones, utilizando un marco de referencia que tiene en consideración las desigualdades regionales en las tendencias de mortalidad. El artículo describe y discute el proceso de divergencia/convergencia regional de la mortalidad, al considerar las contribuciones específicas de los grupos etarios y las causas de muerte para las variaciones en la esperanza de vida. De acuerdo con los resultados, en cierta medida el cambio en la mortalidad en Brasil sigue la teoría de la transición epidemiológica durante el periodo de estudio -por ejemplo, con una importante caída en la mortalidad infantil en todas las regiones de Brasil (primero por las enfermedades infectoparasitarias, y después por las causas asociadas al período perinatal) y el aumento de la ocurrencia de enfermedades crónicas y degenerativas como la principal causa de mortalidad. Sin embargo, algunas características de la transición brasileña no confirmaron el padrón lineal y unidireccional propuesto por la teoría de la transición epidemiológica, lo que ayuda a entender los períodos de divergencia regional en la esperanza de vida (a pesar de las tendencias, a largo plazo, de reducción de las desigualdades regionales). Algunos ejemplos incluyen la epidemia de VIH/SIDA, la persistencia de niveles relativamente altos de otras enfermedades infecciosas y parasitarias, las diferencias regionales en la mejora inesperada en las tasas de mortalidad por enfermedades cardiovasculares y las variaciones rápidas y acentuadas en la mortalidad por causas externas.

Transición de la Salud; Causas de Muerte; Análisis Demográfico
Submitted on 13/May/2016

Final version resubmitted on 18/Aug/2016

Approved on 22/Sep/2016 